\title{
Landuse and surface water quality in an emerging urban city
}

\author{
Olutoyin Adeola Fashae $^{1} \cdot$ Hannah Abiola Ayorinde $^{1} \cdot$ Adeyemi Oludapo Olusola $^{1} \cdot$ Rotimi Oluseyi Obateru $^{1}$
}

Received: 17 July 2018 / Accepted: 23 January 2019 / Published online: 5 February 2019

(C) The Author(s) 2019

\begin{abstract}
The study analyzed the impact of landuse types on surface water quality in an emerging urban city. The objectives were to classify the existing landuse types, examine the variation in water quality across different landuse types, examine the quality of surface water using the water quality index, and compare the water quality parameters with the World Health Organization (WHO) standards. Samples drawn from surface waters were analyzed based on in situ and ex situ analysis according to standard methods. Three landuse types were identified namely residential, vegetated and commercial. The vegetated landuse accounted for the highest landuse type with 74\% of land coverage. One-way analysis of variance was used to determine the variation in water quality parameters within each landuse type. There was a significant variation in total solids $(F=8.677$, $P<0.05)$, total dissolved solids $(F=7.836, P<0.05)$, and total suspended solids $(F=10.365, P<0.05)$. Using the water quality index calculator 1.0, a value of 41 was obtained thereby indicating poor quality. Water quality parameters were compared with World Health Organization (WHO) standards, and it was observed that electrical conductivity, nitrate, phosphate, sulfate, chloride were below WHO permissible limit while total dissolved solids, bacterial load and total solids were above the limit set by WHO. Therefore, there should be a continual intensive water quality monitoring program of surface waters across the area and its immediate environs to maintain healthy lifestyle of the populace and ensure ecosystem balance.
\end{abstract}

Keywords Landuse $\cdot$ Water quality $\cdot$ Urban city $\cdot$ WHO $\cdot$ ANOVA

\section{Introduction}

Water is an essential natural resource which forms the chief constituent of the ecosystem, and it is very vital for sustenance and livelihood of all life forms. Central to human existence is the adequacy of water in terms of quality and quantity (Olusola et al. 2017). Over the years, the impact of landuse changes on water recourses was considerably neglected or seen as a by-product of development (Scanlon et al. 2005; Schilling et al. 2008). Four major direct consequences of landuse on the hydrological cycle have been identified, and these include flood and flood potential; drought; changes in river and groundwater regimes; and water quality in an area (Rogers 2000; Fashae et al. 2017a, b). Appreciating the relationships between landuse and water quality is very important for identifying major threats to water quality (Tiwari et al. 2015; Jiao et al. 2015; Faiilagi

Olutoyin Adeola Fashae

toyinafashae@yahoo.com

1 Department of Geography, University of Ibadan, Ibadan, Nigeria
2015) and the achievement of sustainable development goals. The relationship becomes very relevant in targeting intensive landuse areas and to institute necessary measure to mitigate pollution loading (Faiilagi 2015). Taking into cognizance the intricate spatial and temporal variation in water quality, two prominent types of information required for an effective management of river water quality have been identified. These are spatial and temporal characteristics of the pollutants and information that relates to the propelling factors influencing the water quality (Ifabiyi 2000; Liu et al. 2016; Fashae et al. 2017a; Olusola et al. 2017). In recent years, there has been a rapid declining availability of usable fresh water in terms of water quality and quantity due to unsustainable landuse practices (Ngoye and Machiwa 2004). Water quality has variously been related to landuse in catchment (Levin 2012; Faiilagi 2015; Henderson et al. 2014; Li et al. 2008; Ayeni et al. 2006; Pullanikkatil et al. 2015; Wagner et al. 2013; Olusola et al. 2018), and studies have been focusing on their relationships with water quality variables such as dissolved salts, suspended solid, and nutrients (Mallin 2008; Mathuthu et al. 1997; Elbag 2006; Keshtkar et al. 2010; Olusola et al. 2017). However, Pullanikkatil et al. (2015) argued that there are correlations between systems 
of landuse and water quality, and emphasized the use of water quality index (WQI) in identifying pollution hot spots. Rapid socioeconomic advancement drives landuse change (Wagner et al. 2013) as evident in cases where deforestation, agricultural activities and urbanization, individually or collectively, modify land surface characteristics, alter runoff volume, change water temperature, generate pollution, increase algal production and decrease concentration of dissolved oxygen in water bodies (Irenosen et al. 2012; Jiao et al. 2015; Adediji and Fashae 2014; Olusola et al. 2018). Similarly, according to Faiilagi (2015), surface water can be contaminated by various sources ranging from agricultural runoff (nutrients and chemicals); urban areas (sewage contamination); mixed pollutants discharge from storm water; and likely chemical discharges from commercial and industrial activities. About $80 \%$ of all diseases in the third world countries are directly related to poor drinking water and unsanitary conditions (WHO 2003). Industrial units located at the outskirt and within cities, intensive agricultural practices, indiscriminate disposal of domestic and municipal wastes, and road construction are the sources of surface water and groundwater pollution. Osogbo has witnessed remarkable expansion, growth, and developmental activities such as increase in the number of buildings, road construction, deforestation, and many other anthropogenic activities, since its emergence as the capital of Osun State in 1991 (Taiwo et al. 2014). These have resulted in the emergence of landuse types within the state that reflect uncontrolled planning and management. Due to urbanization, there is rapid population growth in Osogbo Osun state. Rapid population growth drives other urban systems such as urbanization, pollution accumulation, increased technology leading to increase in E-waste, poor housing and sanitary conditions (e.g., open defecation) and waste generation (Taiwo et al. 2014). More importantly, landuse act and policies governing building codes and zonation are not enforced mostly when it comes to urban development, especially across developing countries in Africa (AUC-ECA-AfDB Consortium 2011). The physical transformation in landuse and population density which is characteristic of Osogbo as an emerging urban center exercise significantly impacts on the hydrology and water quality of the neighboring rivers. In other words, the removal of natural vegetation and the subsequent transition into urban landscape increase runoff and sediment loads, thereby increasing the deposition of pollutants from land to surface water bodies (Arnold and Gibbons 1996, Olusola and Fashae 2018, Olusola et al. 2018). This is further supported by the Institute of Water Resources (IWR) (1997) whose findings revealed that different landuse types are characterized by great potential of introducing contaminants into aquatic ecosystems largely due to the diversity of associated human activities. In the purview of the aforementioned, this study therefore assesses the status of dominant landuse types within this emerging urban center and the associated impact on surface water quality. As an emerging urban city in southwestern Nigeria, Osogbo experiences increase in urban population growth which invariably challenges access to safe water and healthy sanitation lifestyle (WHO/ UNICEF JMP 2010). A key aspect of this challenge is the access to safe water either through surface or underground water sources. In most developing tropical countries, the use of surface water for domestic, industrial, and agricultural purposes is clearly evident and as such it calls for the need to carefully appraise the quality of surface water in order to ensure human satisfaction and well-being as well as maintain a safe and healthy environment. This becomes necessary as per capita water demand is increasing while the accessibility to drinking water is declining in Nigeria (Ayeni et al. 2006). The knowledge will assist landuse management and improve landuse planning to control and palliate any adverse impacts on adequate provision of ecosystem services (Falkenmark et al. 2009) which is very key to achieving sustainable development goals (SDG 15) (DeClerck et al. 2016).

\section{Methodology}

\section{Study area}

Osogbo, the capital of Osun state, is located on latitude $7^{\circ} 46^{\prime} \mathrm{N}$ and $4^{\circ} 34^{\prime} \mathrm{E}$ with a land area of about $47 \mathrm{~km}^{2}$ (Fig. 1). The geology consists of Basement Complex which outcrop considerable parts of the area. Rocks of the basement complex in Osogbo are schist and synite which are associated with quartzite ridges. The landscape of Osogbo is situated on a raised land, which is well over $500 \mathrm{~m}$ above the sea level and is drained by River Osun and its tributaries. The climate is humid tropical type and characterized by wet and dry seasons. The wet season begins toward the end of March and ends in October while the dry season begins with the onset of tropical continental air mass commonly referred to as Harmattan. This wind is usually predominant between the months of November and February (Olaniran 2000). Osogbo falls into the southern savanna zone. This zone is a transition between the high forest in the southern part of the country and the north with woodland properties. Agricultural activities such as fish farming, poultry, market gardening, poultry, and cultivation of vegetables, yam and maize are predominant in Osogbo.

\section{Materials and method}

Thirty water samples from different sampling points in Osogbo metropolis (nine within residential, twelve within commercial and nine within vegetated landuse types) were collected in October 2014. The distribution was determined based on the assumption that commercial landuse is 


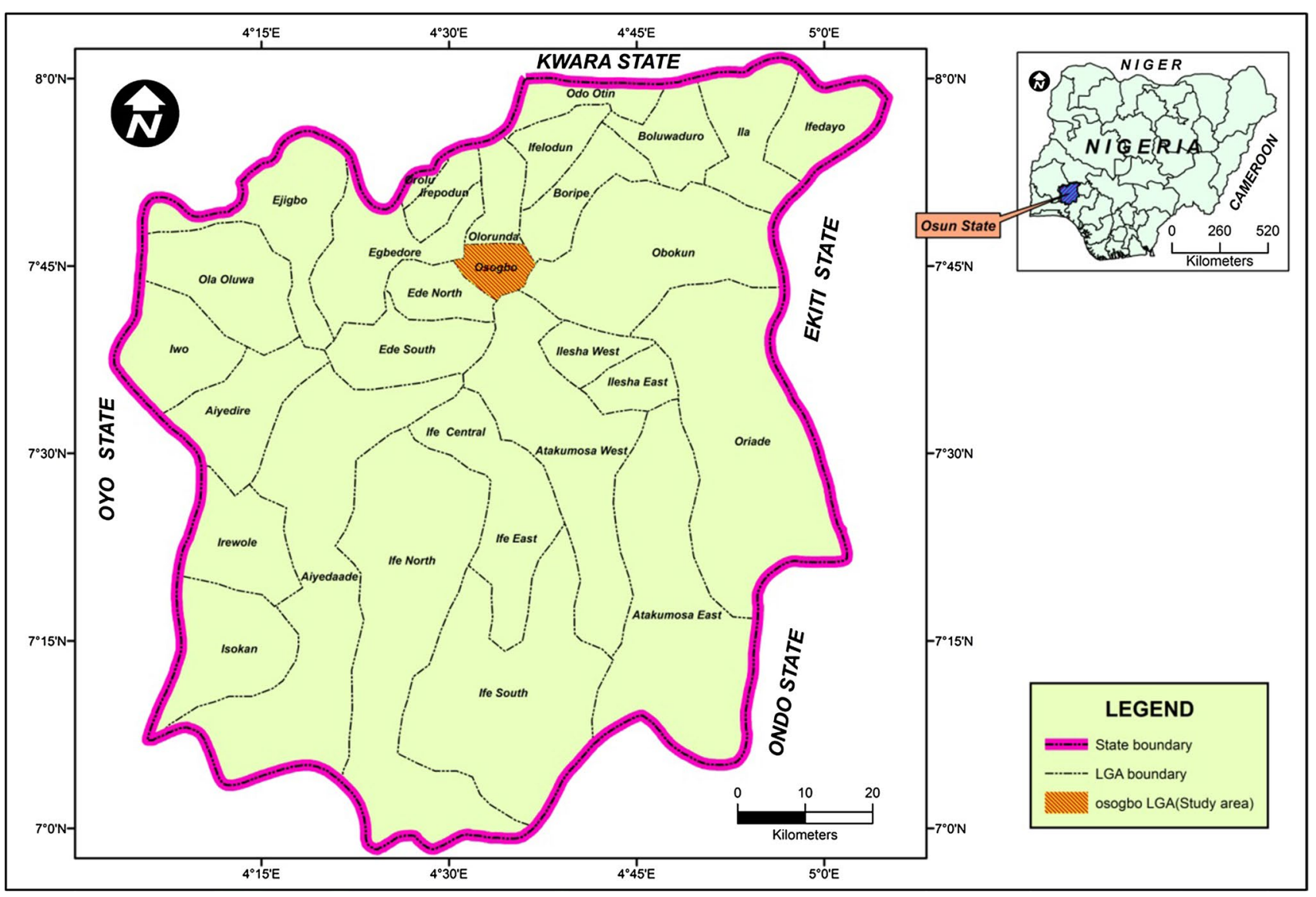

Fig. 1 Map of Osun state showing Osogbo the study area

expected to contribute more pollutants ahead of residential and vegetated. At each sampling point, Global Positioning System (GPS) was used to determine the coordinates and elevation. The water samples were collected using composite sampling method in $75 \mathrm{cl}$ transparent plastic bottles. Samples for biochemical oxygen demand (BOD) were collected in dark glass bottles for incubation while samples for bacteriological analysis were collected in sterilized plain glass bottles. Before sampling, the bottles were rinsed at least thrice with the water to be sampled. The water samples were kept in an ice chest and transported to the laboratory within three hours of sampling. The samples were refrigerated upon receipt in the laboratory to avoid external contamination or deterioration till the time of analysis. Each sample was analyzed for the following parameters: $\mathrm{pH}$, electrical conductivity (EC), temperature, dissolved oxygen (DO), biochemical oxygen demand (BOD), sulfate $\left(\mathrm{SO}_{4}\right)$, phosphate $\left(\mathrm{PO}_{4}\right)$, nitrate $\left(\mathrm{NO}_{3}\right)$, chlorides $(\mathrm{Cl})$, total solids (TS), total dissolved solids (TDS), total suspended solids (TSS), and bacterial load (Fecal Coliform, FC) using standard procedure (APHA 1995).

\section{Laboratory analysis}

Heavy metals were determined using flame atomic absorption spectrophotometer. Anions assessed include nitrate $\left(\mathrm{NO}_{3}\right)$, phosphate $\left(\mathrm{PO}_{4}\right)$, and sulfate $(\mathrm{SO} 4)$, and this was done using HI83200 multispectral bench photometer at a wavelength of $525 \mathrm{~mm}$. Temperature was measured in situ using WET-PRO field kit. The electrical conductivity and total dissolved solids were measured using a JENWAY 3540 Bench combined $\mathrm{pH} /$ conductivity/TDS meter (UK). The Winkler's titration method was used to determine the dissolved oxygen. CFU (colony forming units) per ml was calculated using the method of Cheesbrough (2002).

\section{Geospatial analysis}

The study area map was derived from quick bird satellite imagery. The coordinates of the sampling points obtained in the field using GPS were entered in Microsoft Excel (2007) and imported into ArcGIS 9.3 environment to identify the total extent of the study area from which relevant features like road networks, water bodies, built-up areas and 
vegetation cover were digitized for the purpose of the study (Fig. 2).

Landuse classification and its metrics were carried out using Landsat 2014. The analysis was carried out in Idrissi where major landuse types based on supervised classification were identified. Supervised classification was preferred as the study relies on quantitative analysis. Since the area is well known, geometric correction and validation were further carried out. The mean of the physicochemical and biological parameters were determined. Analysis of variance (one-way ANOVA) was used to determine whether there is variation in characteristics of surface water across different landuse types. The choice of ANOVA was based largely on the structure of the data. The mean value of the physiochemical parameters were compared with the standard set by World Health Organization (WHO 2003) using $t$ test. Water quality index was used to provide a single number that expresses overall water quality within the study area. The descriptive statistics, analysis of variance and t test were done using SPSS
15.0 (statistical product and service solutions). Water quality index was calculated using online National Sanitation Calculator System software also known as NSF information software (Eq. 1). The mean value of each parameter recorded was transferred to a weighting curve chart, where numerical values of $\mathrm{Q}$ were obtained.

$\mathrm{WQI}=\Sigma Q_{\mathrm{n}} W_{\mathrm{n}} / \Sigma W_{\mathrm{n}}$

where WQI is the water quality index; $Q_{\mathrm{n}}$ quality rating for the $n$th water quality parameter; and $W_{n}$ unit weight for $n$th parameter.

The weight factor was derived based on the test's importance to water quality. The index was derived by multiplying the $Q$ by weight factor of each water quality parameter. The index was calculated for each landuse type in the study area, and a general index was calculated combining all the landuse types together. The rating of index ranges from 0 to 100 (Table 1) with 0 indicating very bad water quality and 100 indicating excellent water quality condition.

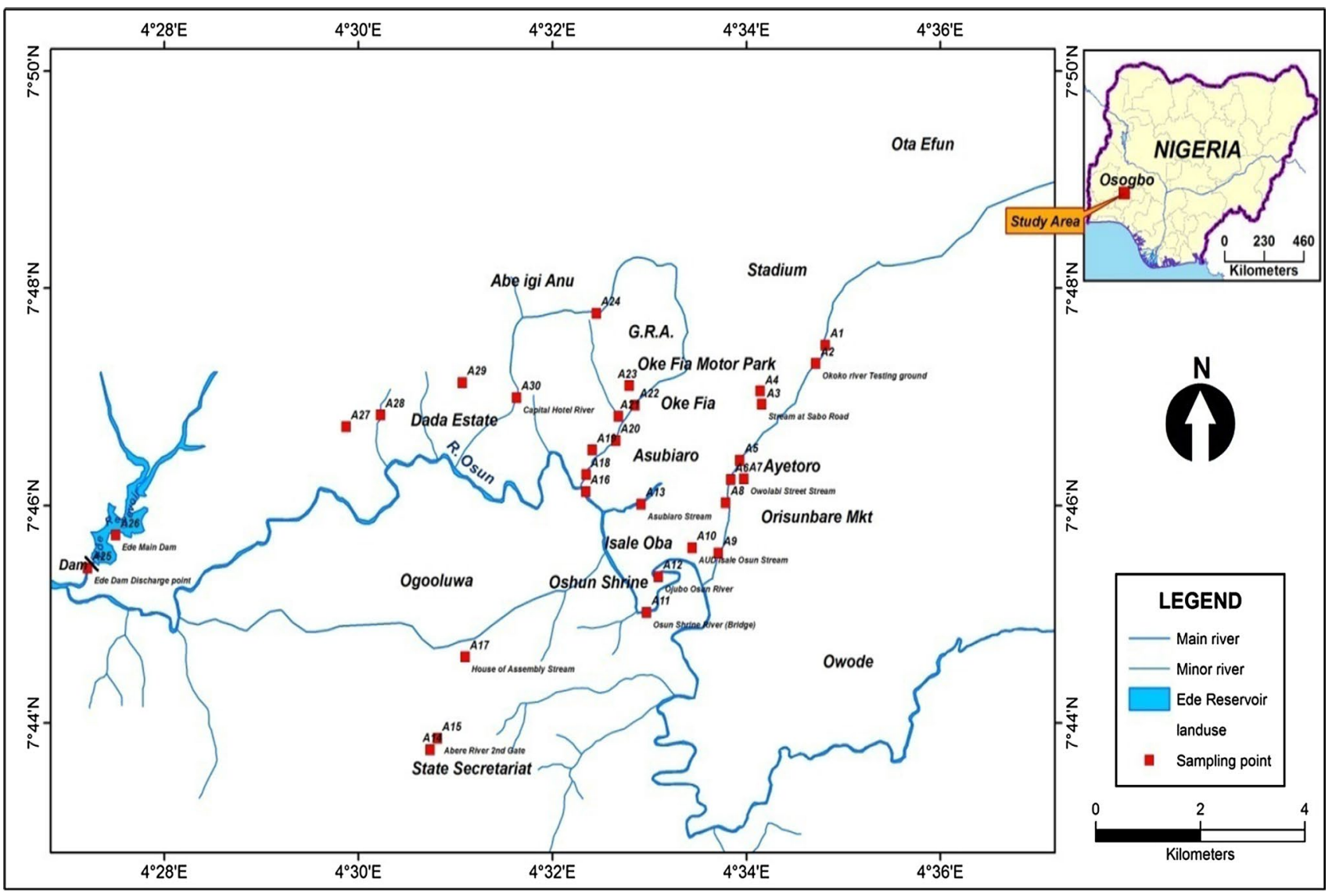

Fig. 2 Map of Osogbo metropolis showing the sampling points 
Table 1 NSF water quality index rating

\begin{tabular}{ll}
\hline Range & Quality \\
\hline $90-100$ & Excellent water quality \\
$70-90$ & Good water quality \\
$50-70$ & Medium water quality \\
$25-50$ & Bad water quality \\
$0-25$ & Very bad water quality \\
\hline
\end{tabular}

\section{Results and discussion}

\section{Landuse classification}

Three landuse types were identified in the study area: residential, commercial, and vegetated (Fig. 3). The percentage area coverage of each is shown in Table 2. The vegetated landuse type accounts for the highest percentage. The residential landuse type is associated with cluster of buildings which supports large human population based on its affiliation to the colonial railway lines and cultural heritage (Adedotun 2015). The commercial landuse type is

Table 2 Areal extent of landuse types in Osogbo metropolis. Source: Author's fieldwork

\begin{tabular}{lcl}
\hline Landuse & Areal extent $\left(\mathrm{Km}^{2}\right)$ & $\begin{array}{l}\text { Percentage } \\
(\%) \text { cover- } \\
\text { age }\end{array}$ \\
\hline Commercial & 24.2 & 8.5 \\
Residential & 49.8 & 17.4 \\
Vegetated & 211.5 & 74.1 \\
\hline
\end{tabular}

characterized by primary economic, secondary economic and tertiary economic activities as well as the existence of financial establishments. The vegetated landuse partly consists of secondary vegetation, dominated by grasses, shrubs, and trees, which are becoming degraded due to pressure from urbanization (Taiwo et al. 2014; Gasu 2016). Agricultural activities, mostly involving the cultivation of vegetables and arable crops for subsistence consumption, are also typical of this landuse type, especially on floodplains.

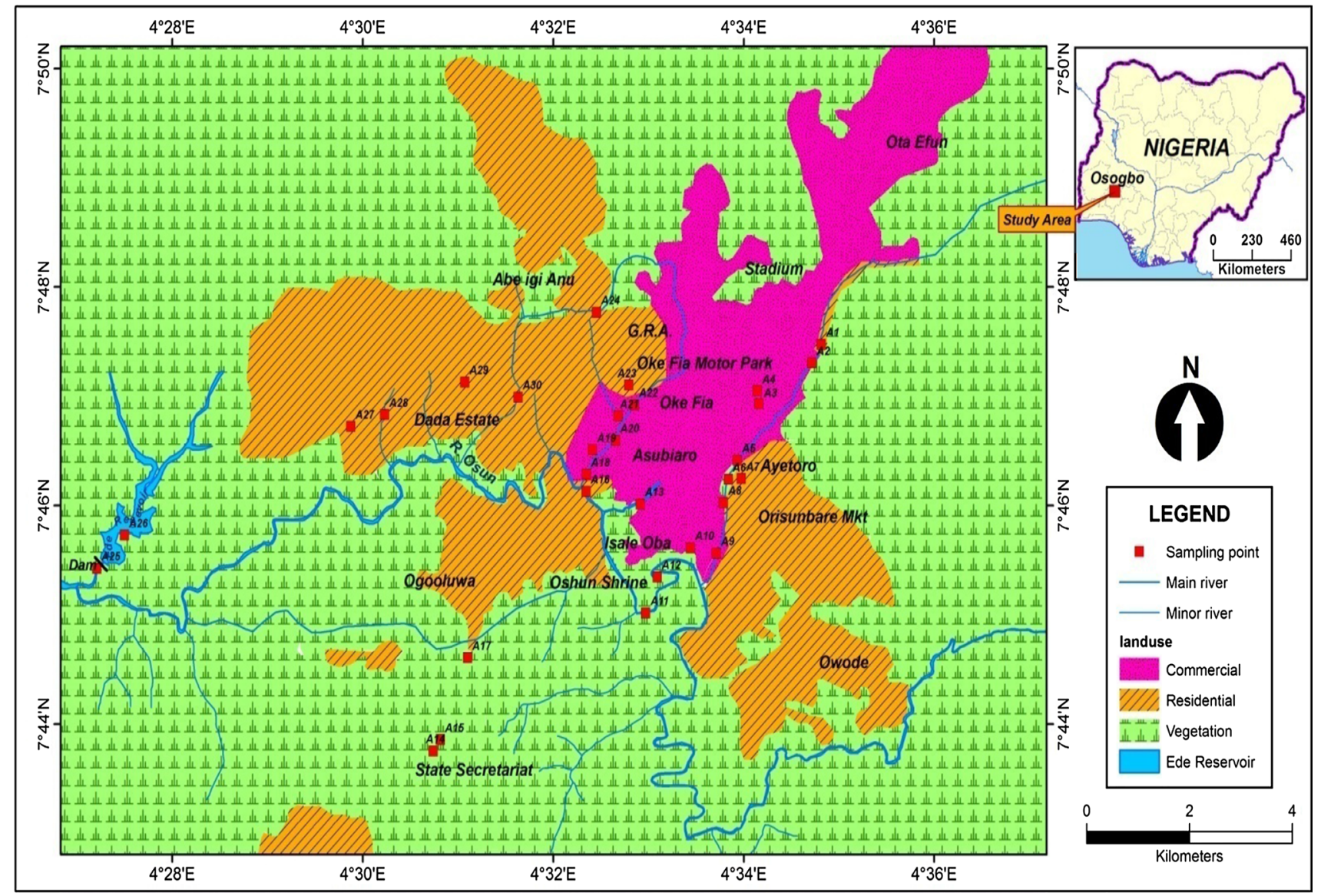

Fig. 3 Map of Landuse types in Osogbo metropolis 


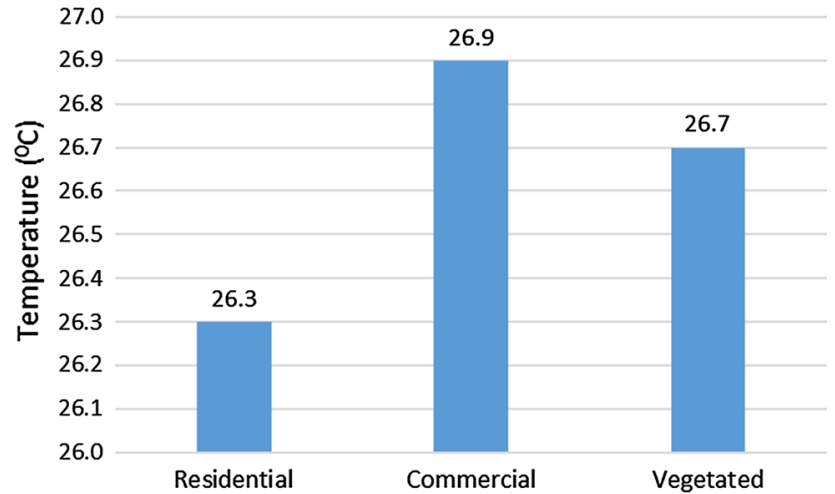

Fig. 4 Variation in temperature

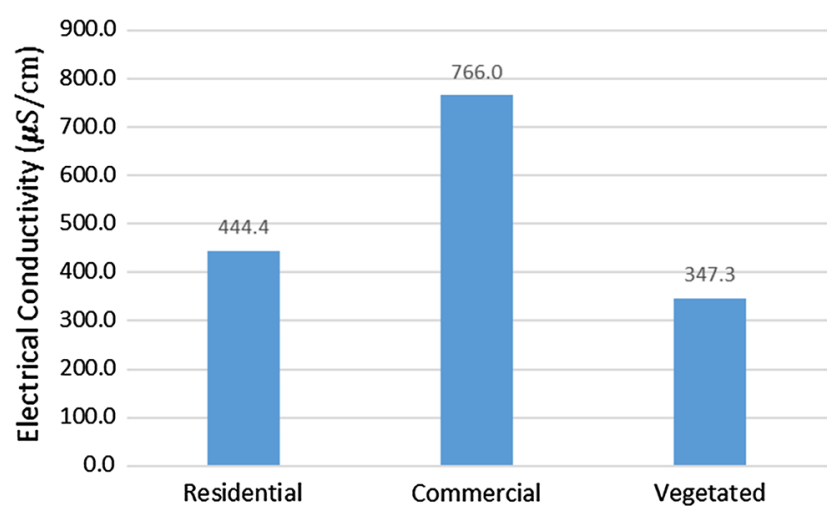

Fig. 5 Variation in electrical conductivity

\section{Physical parameters of surface water quality across landuse types}

The mean values of $\mathrm{pH}$ across the landuse types ranged between 6.0 and 7.9, while temperature mean values were almost the same across the landuse types (Fig. 4). The mean values of electrical conductivity (EC) (Fig. 5) for all the landuse types that is, commercial $\left(766.0 \mu \mathrm{S} \mathrm{cm}^{-1}\right)$, residential $\left(444.4 \mu \mathrm{S} \mathrm{cm}^{-1}\right)$, and vegetated $\left(347.3 \mu \mathrm{S} \mathrm{cm}^{-1}\right)$, were all within the SON (2007) acceptable limit of $1000 \mu \mathrm{Scm}$. High magnitude of EC within the commercial and residential landuse types is closely tied to the secretion of acidic substances such as sulfate, phosphate, and nitrate, contained in solid wastes entering into the water bodies as well as effluent discharged from industries into water ways. Increasing levels of conductivity and cations are the products of decomposition and mineralization of organic materials (Abida 2008). Conductivity level increases with the existence of inorganic suspended solids in runoff as well as the presence of chloride and nitrate from sewage systems which by extension reduces the purity of the surface water (Elberg 2016).

There was a distinct variation in the mean values of total solids (TS) across the three landuse types. Total solids (TS) values in the residential landuse type (Fig. 6) were considerably high $(1262.3 \mathrm{mg} / \mathrm{l})$, while the commercial and vegetated landuse types recorded similar values of $534.2 \mathrm{mg} / \mathrm{l}$ and $541.3 \mathrm{mg} / \mathrm{l}$, respectively. Similar to TS, TDS showed a marked variation across the landuse types, with the residential landuse having the highest mean value of $1039.0 \mathrm{mg} / \mathrm{l}$, while commercial and vegetated landuse recorded $462.3 \mathrm{mg} / \mathrm{l}$ and $444.2 \mathrm{mg} / \mathrm{l}$, respectively (Fig. 6). Also, total suspended solids (TSS) presented relatively high values across the landuse types with residential landuse type recording the highest with mean value of $223.3 \mathrm{mg} / \mathrm{l}$, followed by vegetated $(97.0 \mathrm{mg} / \mathrm{l})$ and commercial $(71.8 \mathrm{mg} / \mathrm{l})$ landuse types. The mean values recorded across the three landuse types violated the permissible limit as set by WHO (2003). The three parameters (TS, TDS, and TSS) to a greater extent evaluate the quality of a drinking water, and their violation limits the aesthetic value of the water by increasing its turbidity which in a way becomes a public health issue (Mendie 2005; Ayeni et al. 2006). Some studies have indicated high turbidity in urban areas (Pullanikkatil et al. 2015) and in areas where sewage is discharged into
Fig. 6 Variation in TS, TDS and TSS

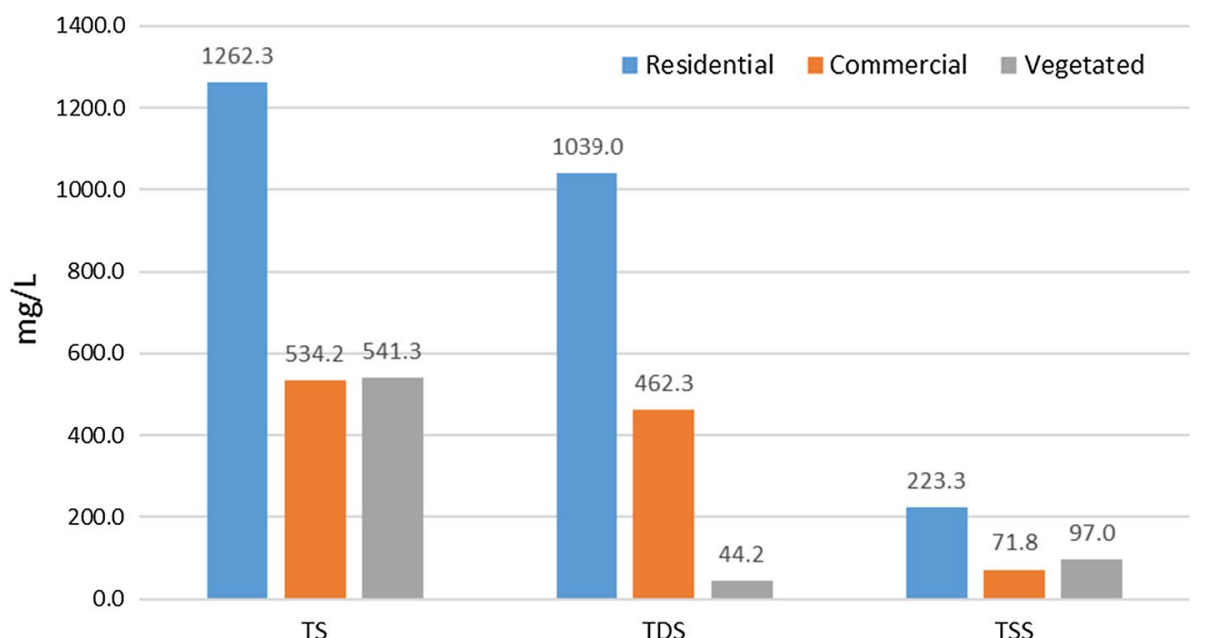

TDS
TSS 
waterways (Mendie 2005). Furthermore, the high values of TS and TDS across the landuse could be attributed to various sociocultural factors such as indecent disposal of household water into water channels, excessive use of fertilizers from farming activities on floodplains and unchecked effluents discharged directly into water bodies.

\section{Chemical parameters of surface water across landuse types}

Nitrate $\left(\mathrm{NO}_{3}\right)$ concentration across the three landuse types was within the WHO (2003) permissible limit of $50 \mathrm{mg} / \mathrm{l}$. However, its mean value within the commercial landuse type $(2.3 \mathrm{mg} / \mathrm{l})$ is higher compared to the other two landuse types, residential and vegetated landuse types $(1.7 \mathrm{mg} / \mathrm{l}$ and $1.6 \mathrm{mg} / \mathrm{l}$, respectively) (Fig. 7). The higher mean value observed within the commercial landuse is closely tied to the slaughter houses located near the water bodies and uncontrolled human activities especially open defecation into water ways (Olusola et al. 2018) which is a common practice as witnessed during data collection. Mean value of phosphate $\left(\mathrm{PO}_{4}\right)$ concentration was higher in commercial and vegetated landuse $(2.3 \mathrm{mg} / \mathrm{l}$ and $2.2 \mathrm{mg} / \mathrm{l}$, respectively) as against $1.7 \mathrm{mg} / \mathrm{l}$ in residential landuse (Fig. 7). Although regulation against $\mathrm{PO}_{4}$ is not listed in the drinking water quality standard in Nigeria (NSDWQ 2007), WHO (1980) recommended a value $\leq 0.05 \mathrm{mg} / \mathrm{l}$ for rivers flowing into a lake or reservoir essentially for controlling eutrophication. The studied river flows into a reservoir downstream; hence, the values as observed across the three landuse types are way beyond the permissible limit. Anthropogenic activities are the main contributors of excessive $\mathrm{PO}_{4}$ into river channels; sewage discharge, runoff from agricultural sites, and the release of detergent during domestic washing especially along river channel sections are common practices (Saksena et al. 2008; Pullanikkatil et al. 2015). The load contribution of detergents raises the level of phosphate in water channels due to the weight of inorganic condensed phosphates (Usharani et al. 2010). As illustrated in Fig. 8, a considerably higher mean value concentration of sulphate $\left(\mathrm{SO}_{4}\right)$ was observed in the commercial landuse $(4.4 \mathrm{mg} / \mathrm{l})$ as against residential and vegetated landuse types (3.8 mg/l and $3.5 \mathrm{mg} / \mathrm{l}$, respectively) (Fig. 7). This can be attributed to domestic and sewage waste which most often than not results in irreversible harmful effects through direct consumption of food supplies in contact with the surface water. However, the presented values are well within the permissible limits; hence, they pose no threat to human system (NSDWQ, 2007). The chloride concentration recorded the highest in the commercial landuse with a mean value of $36.3 \mathrm{mg} / \mathrm{l}$, and this could be as a result of wastewater from factories such as metal plating, automobile repairs, and industrial scraps (Paul 2000). Chloride concentration mean value of $19.9 \mathrm{mg} / \mathrm{l}$ and $17.7 \mathrm{mg} / \mathrm{l}$ were observed in the residential and vegetated landuse, respectively (Fig. 8). The observed mean values in chloride are well within the permissible limit (WHO 2003; NSDWQ 2007). The highest mean value $(4.1 \mathrm{mg} / \mathrm{l})$ for dissolved oxygen (DO) was recorded in the vegetated landuse largely due to productivity of aquatic

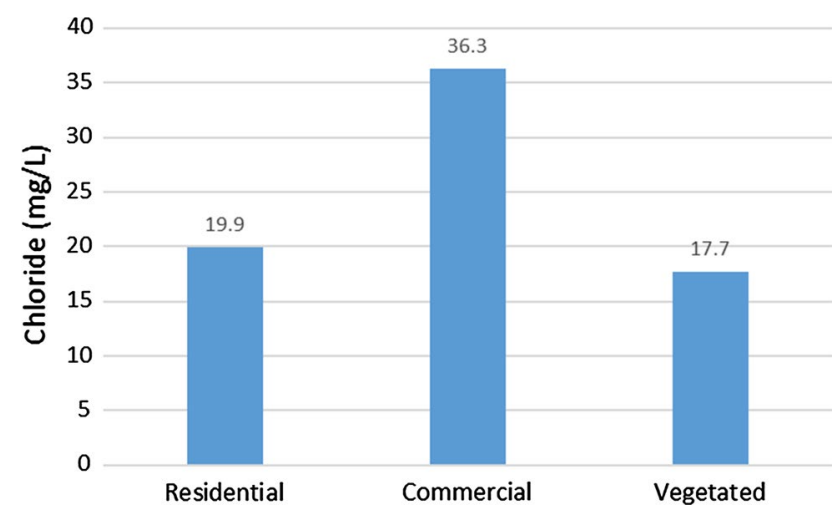

Fig. 8 Variation of chloride
Fig. 7 Variation of sulfates, phosphates and nitrates

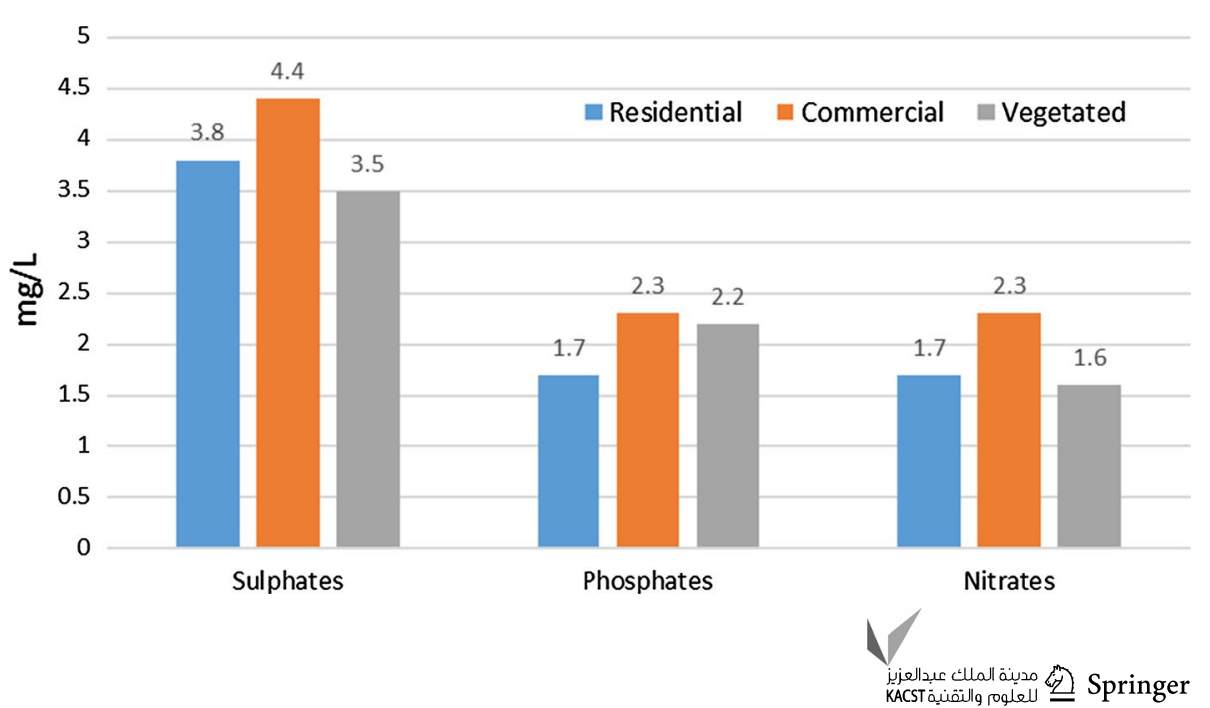


Fig. 9 Variation in DO, BOD and COD

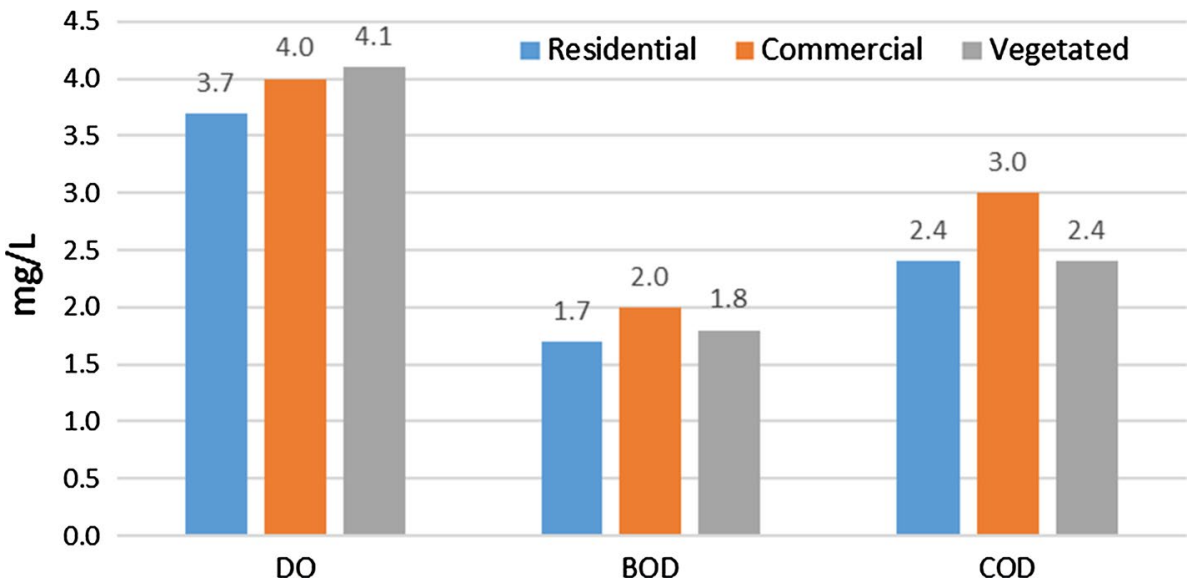

plants (Fig. 9). The commercial and residential landuse had a mean value of $4.0 \mathrm{mg} / \mathrm{l}$ and $3.7 \mathrm{mg} / \mathrm{l}$, respectively. Adequate DO is necessary for good water quality, and it is needed in order to provide for aerobic life forms (WHO 2006). The observed level of dissolved oxygen is within permissible limit of surface water. Chemical oxygen demand (COD) mean value as observed within the commercial landuse $(3.0 \mathrm{mg} / \mathrm{l})$ is slightly different from the residential $(2.4 \mathrm{mg} / \mathrm{l})$ and vegetated $(2.6 \mathrm{mg} / \mathrm{l})$ landuse (Fig. 9), and its presence is an indicator of organic pollution in surface water (Hamner et al. 2006; Nwenya 2006). Biochemical oxygen demand (BOD) mean values of $1.7 \mathrm{mg} / \mathrm{l}$ and $1.8 \mathrm{mg} / \mathrm{l}$ were observed within the residential landuse and vegetated landuse, respectively, and the highest mean value of $2.0 \mathrm{mg} / \mathrm{l}$ was recorded at the commercial landuse. The high occurrence BOD within commercial landuse type may be attributed to discharge of organic wastes such as refuse, human and animal excreta and detergents ejected directly into the water which subsequently resulted into the uptake of oxygen and in the oxidation of these wastes. BOD increases due to biodegradation of inorganic materials which exerts oxygen tension in water bodies (Abida 2008).

\section{Bacterial load (fecal coliform)}

The concentration of fecal coliform (FC) was high in the commercial landuse type (Fig. 10) with a mean value of 5616.7 Cfu. The presence of FC is an indication of sewage contamination (household septic tanks discharging into river channels, abattoirs abutting river channels, agricultural waste from open fields) of the medium and the possible presence of other pathogenic organisms. Fecal coliform bacteria are the most common microbiological contaminants of natural waters. Fecal coliform lives in the digestive tracks of warm-blooded animals including humans (Ho et al. 2003; Wolf-Rainer 2011; Louwanda and William 2013).

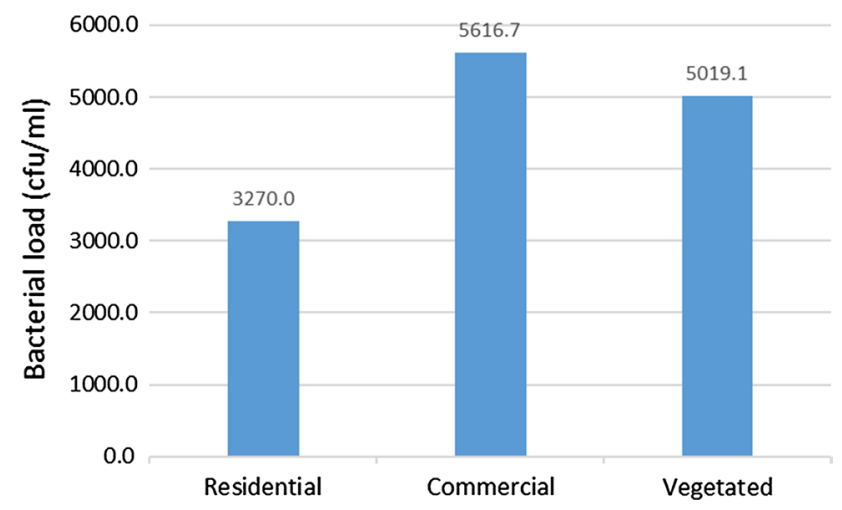

Fig. 10 Variation in bacterial load (fecal coliform)

\section{Implication of variation in water quality within the landuse types}

Analysis of variance test (one-way ANOVA) was used to ascertain the variation in physical parameters (temperature, $\mathrm{pH}$, dissolved oxygen, conductivity, TS, TDS, and TSS) across the selected three landuse types within the study area (Table 3 ). The result revealed that there were significant variations in the following parameters: TS $\left(F_{2,27}=8.677, P<0.05\right)$; TDS $\left(F_{2,27}=7.836, P<0.05\right)$; and TSS $\left(F_{2,27}=10.365, P<0.05\right)$ as shown in Table 3. Possible explanations for these differences may be as a result of the volume of waste from the different landuse types and the type of waste generated.

Furthermore, one-way analysis of variance test (ANOVA) was used to determine the variation in BOD, $\mathrm{COD}, \mathrm{SO}_{4}, \mathrm{PO}_{4}, \mathrm{NO}_{3}, \mathrm{Cl}$, and $\mathrm{FC}$ load among the three different landuse types (Table 4). It was revealed that none of these parameters showed a significant variation across the landuse types. However, the non-significant variation in mean values across the landuse as regards biophysical parameters implies that their concentration are within the permissible limits of surface water based on the global 
Table 3 Variation in the physical parameters of surface water along the landuse types

\begin{tabular}{|c|c|c|c|}
\hline Parameter & Landuse & $d f$ & Sig. \\
\hline Temperature & $\begin{array}{l}\text { Residential } \\
\text { Commercial } \\
\text { Vegetated } \\
\text { Total }\end{array}$ & $\begin{array}{r}2 \\
27 \\
29\end{array}$ & 0.9 \\
\hline $\mathrm{pH}$ & $\begin{array}{l}\text { Residential } \\
\text { Commercial } \\
\text { Vegetated } \\
\text { Total }\end{array}$ & $\begin{array}{r}2 \\
27 \\
29\end{array}$ & 0.6 \\
\hline Dissolved oxygen & $\begin{array}{l}\text { Residential } \\
\text { Commercial } \\
\text { Vegetated } \\
\text { Total }\end{array}$ & $\begin{array}{r}2 \\
27 \\
29\end{array}$ & 0.6 \\
\hline Conductivity & $\begin{array}{l}\text { Residential } \\
\text { Commercial } \\
\text { Vegetated } \\
\text { Total }\end{array}$ & $\begin{array}{r}2 \\
27 \\
29\end{array}$ & 0.1 \\
\hline TS & $\begin{array}{l}\text { Residential } \\
\text { Commercial } \\
\text { Vegetated } \\
\text { Total }\end{array}$ & $\begin{array}{r}2 \\
27 \\
29\end{array}$ & 0.0 \\
\hline TDS & $\begin{array}{l}\text { Residential } \\
\text { Commercial } \\
\text { Vegetated } \\
\text { Total }\end{array}$ & $\begin{array}{r}2 \\
27 \\
29\end{array}$ & 0.0 \\
\hline TSS & $\begin{array}{l}\text { Residential } \\
\text { Commercial } \\
\text { Vegetated } \\
\text { Total }\end{array}$ & $\begin{array}{r}2 \\
27 \\
29\end{array}$ & 0.0 \\
\hline
\end{tabular}

and local standards of WHO (2003) and NSDWQ (2007), respectively.

To account for the difference between standards and observed values, a one-sample t test (Table 5) was conducted to ascertain whether $\mathrm{EC}$, TDS, $\mathrm{FC}, \mathrm{NO}_{3}, \mathrm{PO}_{4}, \mathrm{SO}_{4}, \mathrm{Cl}$, and TS were significantly different in value from the standard set by WHO (2003). The result revealed that EC, bacterial load (fecal coliform), nitrate, phosphate, sulfate, chloride, and TS were significantly different from WHO limits $(P<0.05)$.

\section{Assessment of surface water quality across various landuse types using the water quality index}

Water quality index was further used to assess the overall quality of the surface water across the various landuse types. The index gave a general idea of the quality of surface water based on selected parameters (Table 6).

Based on the eight parameters, the water quality index for residential, commercial, and vegetated landuse types were

Table 4 Variation in the chemical parameters of surface water and the landuse types. Source: Author's fieldwork

\begin{tabular}{|c|c|c|c|c|}
\hline Chemical Parameter & Landuse & $\mathrm{N}$ & df & Sig. \\
\hline \multirow[t]{4}{*}{ BOD } & Residential & 9 & 2 & 0.6 \\
\hline & Commercial & 12 & 27 & \\
\hline & Vegetated & 9 & 29 & \\
\hline & Total & 30 & & \\
\hline \multirow[t]{4}{*}{ COD } & Residential & 9 & 2 & 0.6 \\
\hline & Commercial & 12 & 27 & \\
\hline & Vegetated & 9 & 29 & \\
\hline & Total & 30 & & \\
\hline \multirow[t]{4}{*}{ Sulfates } & Residential & 9 & 2 & 0.2 \\
\hline & Commercial & 12 & 27 & \\
\hline & Vegetated & 9 & 29 & \\
\hline & Total & 30 & & \\
\hline \multirow[t]{4}{*}{ Phosphates } & Residential & 9 & 2 & 0.3 \\
\hline & Commercial & 12 & 27 & \\
\hline & Vegetated & 9 & 29 & \\
\hline & Total & 30 & & \\
\hline \multirow[t]{4}{*}{ Nitrates } & Residential & 9 & 2 & 0.1 \\
\hline & Commercial & 12 & 27 & \\
\hline & Vegetated & 9 & 29 & \\
\hline & Total & 30 & & \\
\hline \multirow[t]{4}{*}{ Chlorides } & Residential & 9 & 2 & 0.2 \\
\hline & Commercial & 12 & 27 & \\
\hline & Vegetated & 9 & 29 & \\
\hline & Total & 30 & & \\
\hline \multirow[t]{4}{*}{ Bacteria } & Residential & 9 & 2 & 0.6 \\
\hline & Commercial & 12 & 27 & \\
\hline & Vegetated & 9 & 29 & \\
\hline & Total & 30 & & \\
\hline
\end{tabular}

Table 5 Water quality factors and weight

42, 39 and 41, respectively (Table 7), hence an indication of poor water quality across the study area.

Similarly, based on the eight parameters, the general water quality index was 41 (Table 8), an indication of a poor water quality (Table 1). The results obtained here are almost at par with those observed by Pullanikkatil et al. (2015) downstream of urban areas of Likangala catchment, 
Table 6 Water quality index across the various landuse types. Source: Author's fieldwork

\begin{tabular}{llll}
\hline Parameters & \multicolumn{2}{l}{ Water quality index } \\
\cline { 2 - 4 } & $\begin{array}{l}\text { Residential } \\
\text { landuse }\end{array}$ & $\begin{array}{l}\text { Commercial } \\
\text { landuse }\end{array}$ & $\begin{array}{l}\text { Vegetated } \\
\text { landuse }\end{array}$ \\
\hline Temperature & 14 & 13 & 14 \\
DO & 4 & 4 & 4 \\
Fecal coliform & 16 & 10 & 14 \\
BOD & 88 & 80 & 85 \\
Phosphates & 29 & 25 & 26 \\
Nitrates & 95 & 94 & 95 \\
Total solids & 20 & 20 & 20 \\
pH & 92 & 92 & 93 \\
\hline
\end{tabular}

Table 7 General water quality index for all the landuse types

\begin{tabular}{ll}
\hline Factors & $\begin{array}{l}\text { Water } \\
\text { quality } \\
\text { index }\end{array}$ \\
\hline Temperature & 14 \\
DO & 4 \\
Bacteria & 14 \\
BOD & 84 \\
Phosphate & 27 \\
Nitrate & 95 \\
TS & 20 \\
pH & 92 \\
\hline
\end{tabular}

southern Malawi. This was further supported by Keshtkar et al. 2010, who linked water quality problem in urban areas to the increasing intensity of anthropogenic activities. Occurrence of pollutants in urban waters as presented in this study clearly reveals the impact of man as he modifies his environment. However, recent studies on urban waters globally established the fact that of great concern are the state of urban waters and the quality of waste being received. Aside metal load and biological contamination as presented in this study, the presence of contaminants of emerging concerns (CECs) such as pharmaceutical and personal care products (PPCPs) and hospital wastes (Barber et al. 2006; Ellis 2006; Fakoya et al. 2018 and Bai et al. 2018) in urban waters coupled with established load of metals and salts in quantities calls for effective monitoring of urban waters and sensitization of urban dwellers.

\section{Conclusion and recommendation}

From the study, it was revealed that quality of surface water in the study area and its environs is very poor. The presence of fecal contamination alone is an indication that a potential health risk exists for individuals exposed to this water, especially downstream. Furthermore, the significant difference between the WHO standard (2003) and some measured physicochemical parameters (total solids, total dissolved solids, total suspended solids, electrical conductivity, phosphate, and sulfate) implied the presence of human waste and other allied materials within the surface water channels. Based on the results of this study, there should be a continual intensive water quality monitoring program of surface waters across the area and its immediate environs. It becomes important to monitor water quality spatio-temporally to understand changes in water quality that occur under different conditions. Therefore, to obtain an adequate collection of baseline data, it will be necessary to monitor water quality over both the wet and dry seasons at a variety of spatial scales. Also, mass education of the local populace on environmental friendliness and its importance are very crucial in maintaining water quality standards. Through such programs, valuable information might be obtained on how to conserve our water ways locally and ensure sustainable and healthy ecosystem.
Table 8 Differences between the parameters and World Health Organization (WHO) limits. Source: Author's fieldwork

\begin{tabular}{llrrrrrl}
\hline Parameters & N & Mean & \multicolumn{1}{l}{ SD } & \multicolumn{1}{l}{$t$} & $d f$ & Sig. & $\begin{array}{l}\text { Test value } \\
\text { (WHO) }\end{array}$ \\
\hline Conductivity & 30 & 543.9 & 476.6 & -5.2 & 29 & 0.0 & 1000 \\
TDS & 30 & 629.9 & 449.7 & 1.6 & 29 & 0.1 & 500 \\
Bacteria load & 30 & 4733.4 & 4898.8 & 5.2 & 29 & 0.0 & 100 \\
Nitrates & 30 & 1.9 & 0.8 & -56.8 & 29 & 0.0 & 10 \\
Phosphates & 30 & 2.1 & 0.9 & -17.7 & 29 & 0.0 & 5 \\
Sulfates & 30 & 4.0 & 1.1 & -5.0 & 29 & 0.0 & 5 \\
Chlorides & 30 & 25.8 & 25.5 & -15.9 & 29 & 0.0 & 100 \\
Cyanides & 30 & 0.0 & 0.0 & -93.5 & 29 & 0.0 & 0.05 \\
TS & 30 & 754.8 & 540.3 & 2.6 & 29 & 0.0 & 500 \\
\hline
\end{tabular}


Open Access This article is distributed under the terms of the Creative Commons Attribution 4.0 International License (http://creativeco mmons.org/licenses/by/4.0/), which permits unrestricted use, distribution, and reproduction in any medium, provided you give appropriate credit to the original author(s) and the source, provide a link to the Creative Commons license, and indicate if changes were made.

\section{References}

Abida B, Harikrishna (2008) Study on the quality of water in some streams of calvary river. J Chem 5(2):37-384. ISSN 0973-4945

Adedotun SB (2015) A study of urban transportation system in Osogbo, Osun State, Nigeria. Eur J Sustainable Dev 4(3):93-101

Adediji A, Fashae OA (2014) Sediment dynamics in a small, 2nd order urban River Awba catchment, Ibadan, Nigeria. J Environ Geogr 7(1-2):23-28

APHA (1995) WPCF, Standard methods for the examination of water and wastewater. American Public Health Association, Washington, DC

Arnold CL, Gibbons CJ (1996) Impervious surface coverage: the emergence of a key environmental indicator. J Am Plan Assoc $62: 243-258$

AUC-ECA - AFDB Consortium (2011) Law policy in Africa: West Africa Regional Assessment. ECA Publications and Conference Management Section (PCMS), p 123

Ayeni AO, Balogun II, Adeaga OA (2006) Impact of selected landuse types on surface water quality downstream of ASA Dam in Kwara State, Nigeria. J Environ Syst 32(3):221-238

Bai X, Lutz A, Carroll R, Ketele K, Dahlin K, Murphy M, Nguyen D (2018) Occurrence, distribution, and seasonality of emerging contaminants in urban watersheds. Chemosphere 200:133-142

Barber LB, Murphy SF, Verplanck PL, Sandstrom MW, Taylor HE, Furlong ET (2006) Chemical loading into surface water along a hydrological, biogeochemical, and land use gradient: a holistic approach. Environ Sci Technol 40(2):475-486

Cheesbrough M (2002) District laboratory practice in tropical countries, 2nd edn. Cambrige University Press, Cambrige, pp 29-30

DeClerck FAJ, Jones SK, Attwood S, Bossio D, Girvetz E, ChaplinKramer B, Enfors E, Fremier AK, Gordon LJ, Kizito F, Lopez Noriega I, Matthews N, McCartney M, Meacham M, Noble A, Quintero M, Remans R, Soppe R, Willemen L, Wood SLR, Zhang W (2016) Agricultural ecosystems and their services: the vanguard of sustainability? Curr Opin Environ Sustain 23:92-99

Elbag MA (2006) Impact of surrounding landuses on surface water quality. M.Sc. Thesis in Environmental Engineering Worcester Polytechnic Institute

Ellis JB (2006) Pharmaceutical and personal care products (PPCPs) in urban receiving waters. Environ Pollut 144:184-189

Faiilagi SA (2015) Assessing the impacts of landuse patterns on river water quality at catchment level: a case study of Fuluasou River Catchment in Samoa (Doctoral dissertation, Massey University)

Fakoya OT, Oluyemi EA, Olabanji IO, Eludoyin AO, Makinde OW, Oyinloye JA (2018) Seasonal variation of heavy metal speciation in soil and stream sediments from hospital waste dumpsite in Ilesa, Southwestern Nigeria. Afr J Environ Sci Technol 12(9):312-322

Falkenmark M, Rockstrom J, Karlberg L (2009) Present and future water requirements for feeding humanity. Food Secur 1(1):59-69

Fashae OA, Olusola AO (2017) Landuse types within channel corridor and river channel morphology of RiverOna, Ibadan, Nigeria. Indones J Geogr 49(2):111-117

Fashae OA, Ayomanor R, Orimoogunje OOI (2017) Landuse dynamics and surface water quality in a typical Urban Centre of South-Western, Nigeria. Analele Universităţii din Oradea, Seria Geografie 27(1):98-107
Gasu MB (2016) Geospatial analysis of land use dynamics in Osogbo between 1986 and 2012. Abuja J Geogr Dev 4:59-68

Hamner S, Tripathi A, Mishra RK, Bouskill N, Broadaway SC, Pyle $\mathrm{BH}$, Ford TE (2006) The role of water use patterns and sewage pollution in incidence of water-borne/enteric diseases along the Ganges River in Varanasi, India. Int J Environ Health Res $16: 113-132$

Henderson L, Mahoney C, McClelland C, Amber M (2014) The effect of Landuse and Land Cover on Water Quality in Urban Environments. Natural Resources and Environmental Sciences (NRES), Kansas State University

Ho KC, Chow YL, Yau JT (2003) Chemical and microbiological qualities of the East River (Dongjiang) water, with particular reference to drinking water supply in Hong Kong. Chemosphere 52:1441-1450

Ifabiyi IP (2000) (eds) Contemporary issue in environmental studies. Haytee Press and Publishing, Ilorin

Institute of Water Resources (IWR) (1997) Landuse effects on Water Quality. Michigan State University, Michigan

Irenosen OG, Festus AA, Coolborn AF (2012) Water quality assessment of the Owena multi-purpose dam, Ondo State, south-western Nigeria. J Environ Prot 3:14-25

Jiao D, Yuan J, Lan F, Qi L, Qiuzhi P, Muyi K (2015) Impacts of landuse on surface water quality in a subtropical river Basin: A case study of the Dongjiang River Basin, Southeastern China. Water. www.mdpi.com/journal/water

Keshtkar AR, Mahdavi M, Salajegheh A, Ahmadi H, Sadoddin A, Ghermezcheshmeh B (2010) Exploring the relationship between landuse and surface water quality using multivariate statistics in arid and semi-arid regions. Desert 16:33-38

Levin KR (2012) Linking land use and water quality: guiding development surrounding durham county's drinking watershed. Master's Thesis, Duke University, Durham

Li S, Gu S, Liu W, Han H, Zhang Q (2008) Water quality in relation to landuse and land cover in the upper Han River Basin, China. Catena 75(2008):216-222

Liu J, Zhang X, Xia J, Wu S, She D, Zou L (2016) Characterizing and explaining spatiotemporal variation of water quality in a highly disturbed river by multi-statistical techniques. SpringerPlus 5(1):1171

Louwanda WJ, William R (2013) extension forestry and natural resources, what is focal coli form? Why is it important? Management 26:9-27

Mallin MA (2008) Comparative impacts of stormwater runoff on water quality of an urban, a suburban, and a rural stream. Environ Monit Assess 159(1-4):475-491

Mathuthu AS, Mwanga K, Simoro A (1997) Impact assessment of industrial and sewage effluents on water quality of the receiving Marimba River in Harare. University of Zimbabwe Publications, Harare, Zimbabwe, pp 43-52

Mendie UE (2005) The theory and practice of clean water production for domestic and industrial use: Purified and package water. Lacto-Medal Ltd, Lagos

Ngoye E, Machiwa JF (2004) The influence of landuse patterns in the Ruvu river watershed on water quality in the river system. Phys Chem Earth 29:1161-1166

Nigerian Industrial Standard, NIS (2007) Nigerian standard for drinking water quality, NIS 554

Nwenya F (2006) Water quality trends in the Eerste river. Western cape, 1990-2005. Unpublished MSc thesis, University of the Western Cape, p 41

Olaniran JO (2000). Rainfall Anomalies in Nigeria: The contemporary understanding. 55th Inaugural lecture, University Press, Ilorin

Olusola A, Fashae O (2018) Urbanization and hydraulic geometry response: a model approach. Int J Water 12(2):103-115

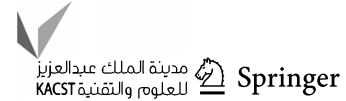


Olusola A, Adeyeye O, Durowoju O (2017) Groundwater: quality levels and human exposure, SW Nigeria. J Environ Geogr 10(1-2):23-29

Olusola A, Onafeso O, Durowoju OS (2018) Analysis of organic matter and carbonate mineral distribution in shallow water surface sediments. Osun Geogr Rev 1(1):106-110

Paul FH (2000) Sulphate and chloride concentration in Texas aquifer. In: Ruth EA (ed) Environmental international. Pergamon Publishing, USA

Pullanikkatil D, Palamuleni LG, Ruhiiga TM (2015) Impact of landuse on water quality in the Likangala catchment, southern Malawi. Afr J Aquat Sci. 1727-9364 (Online), ISSN: 1608-5914 (Print). Journal homepage: http://www.tandfonline.com/loi/taas20

Rogers P (2000) Landuse change in developing countries: comparing India and China. DEAS/HUCE, Harvard University, Cambridge

Saksena DN, Garg RK, Rao RJ (2008) Water quality and pollution status of Chambal River in National Chambal Sanctuary, Madhya Pradesh. J Environ Biol 29:701-710

Scanlon BR, Reedy RC, Stonestrom DA, Prudic DE, Dennehy KF (2005) Impact of landuse and land cover change on groundwater recharge and quality in the southwestern US. Glob Change Biol 11(10):1577-1593

Schilling KE, Jha MK, Zhang YK, Gassman PW, Wolter CF (2008) Impact of land use and land cover change on the water balance of a large agricultural watershed: historical effects and future directions. Water Resour Res 44:1-12

SON (Standard Organization of Nigeria) (2007) Nigerian Standard for drinking water quality. Nigerian Industrial Standard

Taiwo OJ, Abu-Taleb KA, Ngie A, Ahmed F (2014) Effects of political dispensations on the pattern of urban expansion in the Osogbo metropolis, Osun State, Nigeria. In: Proceedings of the 10th international conference of AARSE. October, 2014

Tiwari AK, Singh AK, Singh AK (2015) Hydrogeochemical analysis and evaluation of surface water quality of pratapgarh district, Uttar Pradesh, India. Appl Water Sci 7(4):1609-1623

Usharani K, Umarani K, Ayyasamy PM, Shanthi K, Lakshmanaperumalsamy P (2010) Physico-chemical and bacteriological characteristics of Noyyal River and ground water quality of Perur, India. J Appl Sci Environ Manage 14(2):29-35

Wagner PD, Kumar S, Schneider K (2013) An assessment of landuse change impacts on the water resources of the Mula and Mutha Rivers catchment upstream of Pune, India. Hydrol Earth Syst Sci 17:2233-2246

WHO (2003) Guidelines for drinking-water quality, Volume 1, Recommendations (1st Addendum to 3rd ed.). Geneva: World Health Organization (Electronic version).http://www.who.int/water_sanit ation_health/dwq/gdwq3rev/en/index.html

Wolf-Rainer A (2011) Megacities as sources for pathogenic bacteria in rivers and their fate downstream. Int J Microbiol 2011:1-13

World Health Organization, WHO/UNICEF Joint Water Supply and Sanitation Monitoring Programme (JMP) (2010) Progress on sanitation and drinking-water, 2010 update. World Health Organization, Geneva

Publisher's Note Springer Nature remains neutral with regard to jurisdictional claims in published maps and institutional affiliations. 